\title{
Treatment of severe neuropatic pain for patients with the syndrome of Klippel- Trenaunay-Weber: case report
}

\section{Tratamento de dor neuropática severa em paciente com síndrome de Klippel- Trenaunay-Weber: relato de caso}

\author{
Danielle Cristina de Oliveira Soares ${ }^{1}$, José Nilson Fortaleza de Araújo ${ }^{1}$, Fernando Santiago Lima Verde ${ }^{1}$, Leila Yasmin Maria \\ Cidrão Fortaleza ${ }^{3}$, Grêta Palácio Paulino ${ }^{2}$, Lean de Sousa Oliveira ${ }^{2}$
}

1. Médico do Instituto Dr José Frota (IJF), Fortaleza, Ceará, Brasil. 2. Discente do curso de Medicina do Centro Universitário Christus (UNICHRISTUS), Fortaleza, Ceará, Brasil. 3. Discente do curso de Medicina da Universidade de Fortaleza (UNIFOR).

\begin{abstract}
Introduction: Klippel-Trenaunay-Weber syndrome is a rare congenital anomaly whose etiology has not yet been elucidated. It is characterized by the triad of vascular malformations, cutaneous hemangiomas and overgrowth of bone and soft tissue adjacent. Pain is a common symptom and can be triggered in the following situations: venous disease, scoliosis by the different members and hemangiomas that affect the body surface, the deep planes or viscera. Case report: A female patient, 17, sent from the SARAH Hospital - Fortaleza to the Institute of Clinic Pain José Frota diagnosed with cerebral palsy type triplegia on right eye and anophthalmia featuring an expansive process of vascular origin extending to the paraspinal region, surpassing sciatic foramen and affecting posterior muscles of the left thigh and leg. There are signs of involvement of the sciatic nerve and deep femoral vessels. He was diagnosed with Klippel-Trenaunay-Weber syndrome. She had continuous pain in shock and burning, EVA 10, extending from the lower back, groin and left leg region. The source of hospital treatment consisted of gabapentin $180 \mathrm{mg} 12 / 12 \mathrm{~h}$, codeine $10 \mathrm{mg} 12 / 12 \mathrm{~h}$, ibuprofen $300 \mathrm{mg} 12 / 12 \mathrm{~h}$, codeine/paracetamol $30 \mathrm{mg} 12 / 12 \mathrm{~h}$ and morphine oral $10 \mathrm{mg}$ while in pain, but without pain relief. She also used paroxetine $20 \mathrm{mg}$ daily, due to depression. The painful condition prevented sleep, caused irritation and worsened the quality of life of the patient. She continued treatment with gabapentin $300 \mathrm{mg} 12 / 12 \mathrm{~h}$, dipyrone $500 \mathrm{mg} 12 / 12 \mathrm{~h}$, Methadone 5mg 12/12h and reassessed two weeks showing significant improvement in pain symptoms and sleep, EVA 2. Conclusion: Pain is a symptom commonly described in the clinical picture of patients with this syndrome. The treatment of this disease is still a challenge. The malformations great gifts made it not always possible embolization or painkillers locks. The therapeutic results with strong opioid were satisfactory and have improved the quality of life of the patient.
\end{abstract}

Keywords: : Bad Pain Syndrome. Hemangiomas. Anophtalmos Triplegia. Opioid.

\section{Resumo}

Introdução: A síndrome de Klippel-Trenaunay-Weber é uma anomalia congênita rara cuja etiologia ainda não foi elucidada. Ela é caracterizada pela tríade: malformações vasculares, hemangiomas cutâneos e hiperproliferação de tecidos ósseos e moles adjacentes. A dor é um sintoma frequente e pode ser deflagrada nas seguintes situações: doença venosa, escoliose pela diferença de membros e hemangiomas que acometem a superfície corporal, os planos profundos ou as vísceras. Relato de caso: Paciente do sexo feminino, 17 anos, encaminhada do Hospital SARAH - Fortaleza ao Ambulatório de Dor do Instituto Dr. José Frota com o diagnóstico de paralisia cerebral tipo triplegia à direita e anoftalmia de olho D. Apresenta um processo expansivo de origem vascular estendendo-se da região paravertebral, ultrapassando o forame isquiático e acometendo musculatura posterior da coxa e perna esquerda. Existem sinais de envolvimento do nervo ciático e vasos femorais profundos. Recebeu o diagnóstico de síndrome de Klippel-Trenaunay-Weber. Apresentava dor contínua em choque e queimação, EVA 10, estendendo-se da região lombar, inguinal e membro inferior esquerdo. 0 tratamento do hospital de origem consistia em gabapentina $180 \mathrm{mg} 12 / 12 \mathrm{~h}$, codeína $10 \mathrm{mg}$ 12/12h, ibuprofeno 300mg 12/12h, codeína/paracetamol 30mg 12/12h e morfina 10mg oral se dor, porém sem alívio da dor. Usava também paroxetina $20 \mathrm{mg} / \mathrm{d}$ devido à depressão. 0 quadro álgico impedia o sono, causava irritação e piorava muito a qualidade de vida da paciente. Continuou tratamento com gabapentina $300 \mathrm{mg} 12 / 12 \mathrm{~h}$, dipirona $500 \mathrm{mg} 12 / 12 \mathrm{~h}$, metadona $5 \mathrm{mg} 12 / 12 \mathrm{~h}$ e reavaliada com duas semanas apresentava melhora importante do quadro álgico e no sono, EVA 2. Conclusão: A dor é um sintoma comumente descrito no quadro clínico dos portadores desta síndrome, sendo ainda o tratamento dessa enfermidade um desafio. As grandes má-formações presentes nem sempre possibilitam embolizações ou bloqueios analgésicos. Nesse caso, o resultado terapêutico com opioide forte foi considerado satisfatório, tendo melhorado a qualidade de vida da paciente.

Palavras-chave: Síndrome dor má formação. Hemangiomas.Triplegia. Anoftalmia. Opioide.

\section{INTRODUCTION}

Klippel-Trenaunay-Weber Syndrome (SKTW) is a set of signals consisting of cutaneous hemangiomas, various venous abnormalities and hypertrophy of bones and soft tissues and at least two of these clinical signs. It was described in 1900 by Maurice Klippel and Paul Trenaunay. Seven years later, Frederick Parkes Weber described some cases with signs similar to those described previously associated with arteriovenous fistulas. It was shown that the two diseases are part of the same 
clinical picture with different degrees of severity ${ }^{1}$.

The SKTW is a rare congenital mesodermal disorder of unknown etiology and variable expression. It can result from a mutation in embryogenesis or have autosomal dominant with incomplete penetrance. This syndrome can be transmitted to many generations of phenotypically normal individuals. The pathogenetic mechanism related to increased angiogenesis consists of mutations in the angiogenic factor gene (VG5Q) via transcription and increased activity. The VG5Q gene has been identified in blood vessels, being secreted during angiogenesis and promoting increased endotelial ${ }^{1-4}$ cell proliferation. The Triad is present in $63 \%$ of patients, while $37 \%$ have only two signals. The syndrome affects, in most cases, a single lower limb (80-85\%). Arteriovenous malformations can be most varied, from small capillaries changes, varicosities, to arteriovenous fistulas or giant cavernous hemangiomas. The fragility of the vessel causes bleeding risk is always present in such pacientes ${ }^{1-3}$. This syndrome has no prevalence on sex or ethnicity and usually appears at birth or in childhood and adolescence ${ }^{4}$.

Pain is the most common symptom and can be triggered by venous disease or by scoliosis generated by the different members or even by hemangiomas that affect the various regions of the body surface, deep planes or entrails ${ }^{1}$.

\section{CASE REPORT}

A female patient, 17, with cerebral palsy type triplegia and anophtalmia on the right side presented bone deformities and soft tissue, scoliosis and extensive expansive process of vascular origin primarily affecting the left lower limb. There was no cognitive impairment and laboratory tests evidenced normal renal and hepatic functions. Also there was no history of heart disease or asthma.

The patient was diagnosed with Klippel-Trenaunay syndrome, a syndrome with two signals: vascular changes and bone deformities and soft tissue (Figure 1 and 2). The growth of vascular expansive process caused a severe neuropathic pain type more severe. Hemangioma embolization was indicated but it was not possible to perform due to its large extent and involvement of deep vessels.

On her spine, there were RNM on pelvis and lower limbs on $13 / 01 / 2009$, hemangioma on the left paraspinal region, which exceeded the sciatic foramen affecting pelvic region, retroperitoneal and all the muscles of the posterior region of the left lower limb. There were signs of involvement of the deep femoral vessels, sciatic nerve compression and the tibial vascular-neural beam. On the spinal cord it was found a narrow cervical canal without any evidence compression and thickness, normal signal strength throughout the spinal extension. Multiple splenic nodules of unspecific nature and calcification of the left adrenal gland were shown.

Continuous pain in shock and burning, EVA 10, located in the lower back, groin and left leg region was reported. Improving or worsening pain was not identified. The table prevented sleep, caused irritation and important emotional lability. Was using gabapentin $180 \mathrm{mg} 12 / 12 \mathrm{~h}$, codeine $10 \mathrm{mg} 12 / 12 \mathrm{~h}$, ibuprofen $300 \mathrm{mg} 12 / 12 \mathrm{~h}$ in a single manipulated tablet also codeine association/paracetamol $30 \mathrm{mg} / 500 \mathrm{mg} 12 / 12 \mathrm{~h}$. The pain did not alleviate with these medications, and oral morphine $10 \mathrm{mg}$ was then prescribed. The patient reported the use of morphine three times a day and how she was very sleepy, without pain relief. Paroxetine $20 \mathrm{mg}$ per frame for depression was also used.

In the first query on clinic pain the home oral maintenance therapy was modified. The dose of gabapentin was increased to $300 \mathrm{mg} 12 / 12 \mathrm{~h}$, suspended ibuprofen, codeine and morphine and dipyrone were initiated on $500 \mathrm{mg} 12 / 12 \mathrm{~h}$ and still methadone hydrochloride $5 \mathrm{mg} 12 / 12 \mathrm{~h}$. After two weeks of the new treatment, a revaluation was carried out and it was found a significant improvement in pain symptoms with adequate sleep and improved quality of life. EVA 2 was reported at the time. He returned 45 days informing the occasional episode of pain daily, intensive and accompanied by cramps on the leg. Methadone dose was increased to $10 \mathrm{mg} 12 / 12 \mathrm{~h}$.

The patient signed the Clarified Consent Form (IC), agreeing to have her medical history to carry on with this work, contributing to the scientific community.
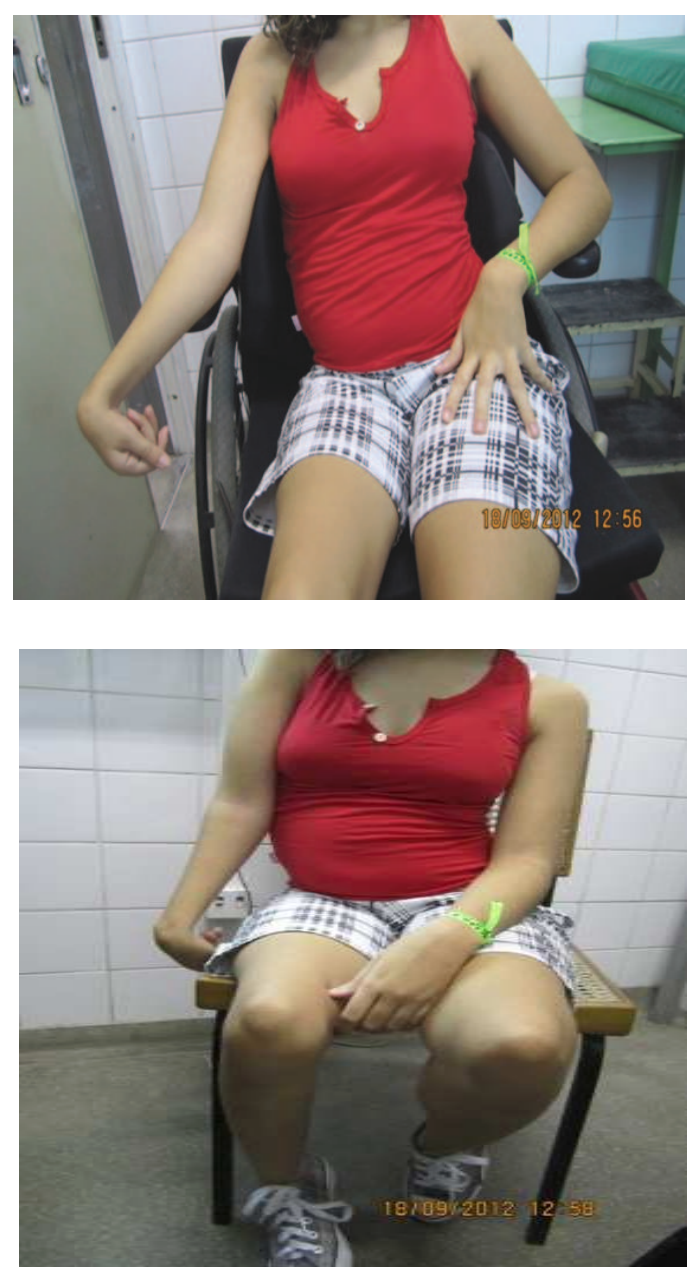


\section{DISCUSSION}

Vascular malformations are rare causes of neuropathy of the sciatic nerve and the most common causes such as nerve root compression should be excluded before the diagnosis ${ }^{5}$.

The patient had severe pain, neuropathic type and the difficulty of treatment caused by the size and the anatomic relationships of the hemangioma. As current guidelines for the treatment of neuropathic pain, one should be absolutely sure of the diagnosis and trying to treat the source of pain are the first measures to be taken ${ }^{6-8}$. Embolization was not possible to be so conducted as analgesics lock sciatic nerve because of the anatomical difficulty.

Gabapentin is an inhibitor of the calcium channel voltagedependent considered first-line drug for the treatment of neuropathic pain as well as tricyclic antidepressants (amitriptyline, nortriptyline and desipramine), selective inhibitors for receiving serotonin and noradrenaline (duloxetine and venlafaxine) and lidocaine. It has been observed that the use of gabapentin dose was lower than usual, and then increased to $600 \mathrm{mg}$. The maximum daily dose is $3600 \mathrm{mg}$, usually divided into three or four outlets. The increase should be gradual and clinically monitored because side effects, especially sedation may appear ${ }^{6,7}$. Tramadol and other opioid analgesics have shown effectiveness in treating various conditions of neuropathic pain. There is always concern as to the long-term use of these medications. Therefore, second-line drugs should be considered for use only when the pain is not controlled with the drugs of first choice. In some situations opioids are considered as the first line, acute neuropathies, neuropathies secondary to cancer, exacerbation episodes of severe neuropathies and as the first-line drugs start their action. Tramadol is considered a drug to be indicated for the treatment of neuropathic pain, as well as the effect $\mu$ opioid agonist, has action as an inhibitor of the reuptake of serotonin and noradrenaline, acting on two mechanisms for pain relief ${ }^{7,8}$.

Codeine is also not suitable for individuals who concomitantly use selective serotonin reuptake inhibitors (SSRI). Codeine is a prodrug which is metabolized to morphine analgesia active responsible manner by CYP2D6 cytochrome family. Particularly, quinidine and Selective Serotonin Reuptake Inhibitors are drugs that produce significant inhibition of CYP2D6. Thus, codeine, and hydrocodone and oxycodone, that also need this route for metabolizing an active form, are drugs with analgesic action at low ISRS $^{9}$. They have been used as the strong opioid on patients with exacerbation of neuropathy. It is advisable that they be chosen because they present a methadone agonist activity $\mu$, and action non-competitive with NMDA antagonist receptor. In neuropathic pain there occurs neuronal plastic changes including increased number of ion channels, changes in permeability and its distribution, changes in response to catecholamines, and finally activation of NMDA receptors by glutamate. Methadone seems to offer an advantage in controlling neuropathic pain when compared to other strong opioids ${ }^{10,11}$.

Since there is little evidence of the benefits of ibutrofen for neuropathic pain and for its major renal and gastrointestinal side effects with their chronic use, they have been suspended. Dipyrone was associated with treatment as an adjuvant for acute control of severe pain.

Despite the good response in pain control with these medications they cause concern regarding the use of strong opioids in young patients with non-cancer pain. However, the difficulties regarding the anatomy and drug interactions, made the possibilities very small for adopting as the proper treatment of choice.

Another option could be the exchange of paroxetine, another anti-depressant that is first-line treatment for neuropathic pain, such as dual inhibitors. We scheduled discontinued use of methadone after some time and observed the response of the patient. There was spinal stimulator implantation report T9 and T10 and an excellent response for relief of pain, treatment with a chance for young patients with severe pain ${ }^{12}$.

A good choice for the analgesic treatment would be epidurals. Computed tomography (CT) of the spine should be carried out in order to evaluate the existence of epidural hemangioma, common change in SKTW, as well as spinal or brain arteriovenous fistula, is essential before performing this procedure. There were spinal hemangioma rupture reports causing progressive ${ }^{13}$ paraplegia. However, the patient had an extensive hemangioma already attacking the paraspinal region that went beyond the sciatic foramen and retroperitoneal. Later on, the pain increased, with the indication of the hemangioma. As it was an urgent treatment, it was chosen to start the medications orally and after the realization of the tomography.

Few reports have found on this syndrome to be rare and. There should be an in-depth study directing its analgesic treatment aiming to promote improvement in the quality of life for patients with this syndrome.

\section{REFERENCES}

1. Villela ALC, Guedes LGS, Paschoa VVA, David AB, Tenório TM, Lamego HP Júnior, et al - Perfil Epidemiológico de 58 portadores de síndrome de KlippelTrenaunay-Weber acompanhados no Ambulatório da Santa Casa de São Paulo. J vasc bras. 2009;8(3):219-224. doi: http://dx.doi.org/10.1590/S167754492009000300006.

2- Barbara DW, Wilson JL. Anesthesia for surgery related to Klippel-Trenaunay syndrome: a review of 136 anesthetics. Anesth Analg. 2011;113(1):98-102.

\section{doi:10.1213/ANE.0b013e31821a03c2.}

3- Lee JH, Chung HU, Lee MS. An anesthetic management of a patient with Klippel-Trenaunay syndrome. Korean J Anesthesiol. 2012 Jul; 63(1):90-91. doi: 10.4097/kjae.2012.63.1.90.

4- Leon CA, Braun LR Filho, Ferrari MD, Guidolin BL, Maffessoni BJ. Síndrome de Klippel-Trenaunay - relato de caso .An. Bras. Dermatol. 2010 Jan.- Feb. 85(1): 
93-96. doi: http://dx.doi.org/10.1590/S0365-05962010000100015.

5. Van Gompel JJ, Griessenauer CJ, Scheithauer BW, Amrami KK, Spinner RJ. Vascular malformations, rare causes of sciatic neuropathy: a case series. Neurosurgery. 2010 Oct; 67(4):1133-1142. doi: 10.1227/ NEU.0b013e3181ecc84e.

6. Dworkin RH, Connor AB, BackoniaM, Farrar JT, Finnerup NB, Jesen TS, et al. Pharmacologic management of neuropathic pain: evidence-based recommendations. Pain. 2007 Dec;132(3):237-251.

7. Dworkin RH, Connor AB, Audette J, Baron R, Gourlay GK, Haanpää, ML. Recommendations for the pharmacological management of neuropathic pain: an overview and literature update. Mayo Clin Proc. 2010 Mar;85(3 Suppl):S3-S14. PubMed Central PMCID: 2844007.

8. Moulin DE, Clark AJ, Gilron I, Ware MA, Watson CP, Sessle BJ, et al Pharmacological management of chronic neuropathic pain - consensus statement and guidelines from the Canadian Pain Society. Pain Res Manag. 2007. 12(1):13-21.
9. Miller RD. Miller`s Anesthesia. 7. ed. EstadosUnidos: Elsevier; 2009. 511p.

10. Gagnon B, Almahrezi A, Schreier G. Methadone in the treatment of neuropathic pain. Pain Res Manag. 2003; 8(3):149-54.

11. Juver JPS, Figueiredo NV, Barrucand L, Tostes MA. et al - Uso da metadona no tratamento da dor neuropática não-oncológica. Relato de Casos. Rev Bras Anestesiol, 2005 Jul-Ago; 55(4):450-459. doi: http://dx.doi.org/10.1590/S003470942005000400010

12. Franz RW, Prok A. Klippel-Trenaunay syndrome: treatment of lower extremity pain with a spinal cord stimulator. Vascular. 2009 Sep-Out; 17(5):293-295.

13. Yamada Y, Yamada K, Yamamoto K, Takeuchi A, Tsuchiya H. Epidural block for lower limb amputation in a patient with Klippel-Trenaunay-Weber syndrome. Masui. 2013 Feb; 62(2):213-6. PubMed PMID: 23479928.

14. CEBECl, E; ET AL. Cebeci E, Demir S, Gursu M, Sumnu A, Yamak M, Doner B, et al. A Case of newly diagnosed Klippel Treunanay Weber Syndrome presenting with nephrotic syndrome. Case reports in nephrology. 2015; 2015: 1-4. doi: http://dx.doi.org/10.1155/2015/704379

\section{Como citar este artigo/How to cite this article:}

Soares DCO, Araujo JNF, Verde FSL, Fortaleza LYMC, Paulino GP Oliveira LS . Treatment of Severe Neuropatic Pain for Patients with the Syndrome of KlippelTrenaunay-Weber . J Health Biol Sci. 2016 Ouc-Dec; 4(4):271-274 